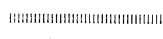
論 文

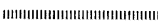

\title{
鉄鉱石焼結鉱の気孔形成過程とそのモデル化
}

\author{
佐藤 駿* ・ 川口尊三* 一一伊達稔 $* 2 \cdot$ 吉永真弓 $* 3$
}

\section{Pore Forming Process on Iron Ore Sinter and Its Model}

\author{
Shun Sato, Takazo Kawaguchi, Minoru Ichidate and Mayumi Yoshinaga
}

\begin{abstract}
Synopsis :
On the controlling factors for sinter qualities, sinter porosity plays an important role together with the mineral composition. The present work was carried out to study on sinter pore and its forming mechanism by pot tests and to develop the sinter porosity evaluation model.

Pores in sinter were formed as the pores in raw mix bed were changed and redistributed by the forming sinter melt. predicted porosity in sinter was described by the melting ratio of raw materials and the fluid index of sinter melt. Sinter porosity was measured on the small open pores below $0.5 \mathrm{~mm}$ in diameter and the all closed pores by JIS method.
\end{abstract}

The calculated porosities by the model were in good agreement with the observed ones.

Key words : agglomeration; sinter; iron ore ; porosity ; modelling.

\section{1. 緒}

\section{言}

高炉门の主要装入物として焼結鉱の品質は高炉操業の安 定と諸元改善に重要な影響を及ぼしいる。焼結鉱の気 孔は強度面では構造欠陷部分として関与するため気孔率 の増加は強度低下を招くが, 被還元性の点では還元ガス との接触面積を増して還元率の问上に寄与する.

従来焼結鉱品質に関する知見や解析は主として化学成 分や焼絬鉱組織面から論じられることが多いが，通常製 造される焼結鉱の組成範囲は狭くこれだけで品質の变化 を十分に説明できない。

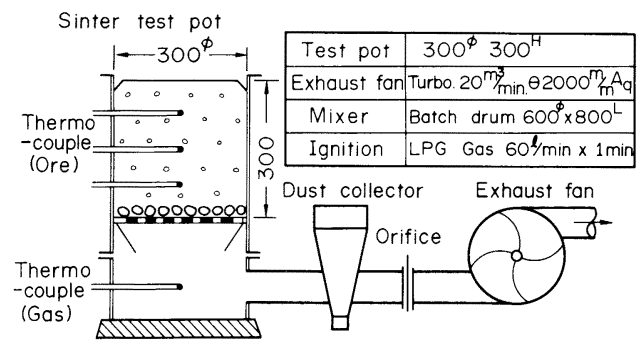

Fig. 1. Outline of sinter test procedure and apparatus.
しかしながら最近になつて焼結鉱品質の物理的側面の

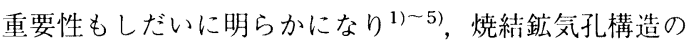
解析結果も増えつつある。

本研究ではこのように焼結鉱の品質と関係の深い気孔 の形成過程について検討するとともに，その実験と解析 結果から焼結鉱品質評価モデルの一環として焼結鉱気孔 率を定量的に予測するモデルを開発し実測結果との対忍 性を検討した。

\section{2. 実 験 方 法}

\section{$2 \cdot 1$ 供試料及び実験装置}

Table 1 には実験に用いた鉄鉱石原料の性状を示し た。原料は焼結用粉鉱として通常よく使用されるもので 焼結鍋試験の原料配合はこれら主原料をそれぞれ $66 \%$ ， 返鉱 $16.5 \%$, 石灰石 $13 \%$ 及び粉コークス $4.5 \%$ 一定 構成の単味配合とした。 Fig. 1 には実験に用いた焼結 鍋試験装置を示す. 本装置は製銑部会法 ${ }^{6)}$ に準拠し上記 配合原料はバッチ式ドラムミキサーで 3 min 混合後さら に適量の水分 $(4 \sim 7 \mathrm{wt} \%)$ を加えて $3 \mathrm{~min}$ 造粒した。 事前処理された原料は鍋に均一に装入されプロパンガス で表面点火した後, 風箱に接続された排風機により焼結

昭和 57 年 9 月本会講演大会にて発表 盼和 61 年 6 月 $2 \mathrm{H}$ 受付 (Received June 2, 1986)

* 住友金属工業 (株) 総合技術研究所 (Technical Research Laboratories, Sumitomo Metal Industries, Ltd., 16 Oaza-Sunayama Hasaki-cho Kashima-gun Ibaraki pref. 314-02)

*2 住友金属工業 (株) 総合技術研究所 工博 (Technical Research Laboratories, Sumitomo Metal Industries, Ltd.)

*3 住友金属 L. 業 (株) 総命技術研究所 理博 (Technical Research Laboratories, Sumitomo Metal Industries, Ltd.) 
Table 1. Chemical composition and other characteristics of iron ore materials.

\begin{tabular}{|c|c|c|c|c|c|c|c|c|c|c|c|c|}
\hline $\begin{array}{c}\text { Materiels } \\
\text { (Unit) }\end{array}$ & $\begin{array}{l}\text { T. Fe } \\
\text { wt } \%\end{array}$ & $\begin{array}{l}\mathrm{CaO} \\
\text { wt } \%\end{array}$ & $\begin{array}{l}\mathrm{SiO}_{2} \\
\text { wt } \%\end{array}$ & $\begin{array}{l}\mathrm{Al}_{2} \mathrm{O}_{3} \\
\text { wt } \%\end{array}$ & $\begin{array}{l}\mathrm{MgO} \\
\text { wt } \%\end{array}$ & $\begin{array}{l}\mathrm{FeO} \\
\text { wt } \%\end{array}$ & $\begin{array}{c}\text { CW } \\
\text { wt \% }\end{array}$ & $\begin{array}{c}\begin{array}{c}\text { Apparent } \\
\text { density }\end{array} \\
\mathrm{g} / \mathrm{cm}^{3}\end{array}$ & $\begin{array}{c}\begin{array}{c}\text { True } \\
\text { density }\end{array} \\
\mathrm{g} / \mathrm{cm}^{3}\end{array}$ & $\begin{array}{c}\text { Charac- } \\
\text { teristic } \\
\text { particle } \\
\text { size } \\
\text { (Median) } \\
\text { mm }\end{array}$ & $\begin{array}{c}\text { Porosity } \\
\text { vol } \%\end{array}$ & $\begin{array}{c}\text { Porosity } \\
\text { after } \\
\text { dehydration } \\
\text { vol } \%\end{array}$ \\
\hline Ore A & 64.7 & 0.1 & 1.57 & 1.53 & 0.08 & 2.95 & 3.30 & 4.03 & 4.61 & 0.51 & 12.6 & 25.7 \\
\hline Ore B & 62.0 & 0.1 & 4.30 & 2.85 & 0.40 & 0.10 & 1.20 & 4.07 & 4.60 & 1.01 & 11.5 & 16.8 \\
\hline Ore C & 64.7 & 0.1 & 4.50 & 0.60 & 0.45 & 0.10 & 0.70 & 4.51 & 5.02 & 0.84 & 10.0 & 13.8 \\
\hline Ore D & 61.3 & 0.1 & 6.30 & 2.75 & 0.50 & 0.10 & 1.45 & 4.21 & 4.73 & 1.60 & 11.0 & 14.6 \\
\hline Ore $E$ & 64.9 & 1.00 & 3.60 & 0.40 & 0.50 & 21.9 & 0.10 & 4.27 & 4.98 & 0.30 & 14.3 & 16.8 \\
\hline Ore F & 64.5 & 1.64 & 4.67 & 0.89 & 1.07 & 25.6 & 0.10 & 4.71 & 4.72 & 1.42 & 0.2 & 2.2 \\
\hline Ore $\mathrm{G}$ & 57.3 & 0.1 & 6.25 & 3.35 & 0.70 & 0.10 & 8.08 & 3.45 & 4.06 & 2.40 & 15.0 & 32.0 \\
\hline $\begin{array}{c}\mathrm{B}+\mathrm{E} \\
(1: 1)\end{array}$ & 63.5 & 0.6 & 3.95 & 1.63 & 0.45 & 11.0 & 0.65 & 4.17 & 4.78 & 0.45 & 12.9 & 16.4 \\
\hline $\begin{array}{c}B+C \\
(1: 1)\end{array}$ & 63.9 & 0.1 & 4.40 & 1.73 & 0.43 & 0.10 & 0.95 & 4.28 & 4.80 & 0.90 & 10.8 & 15.3 \\
\hline $\begin{array}{c}\mathrm{B}+\mathrm{A} \\
(1: 1)\end{array}$ & 63.4 & 0.1 & 2.94 & 2.19 & 0.24 & 1.53 & 2.25 & 4.05 & 4.60 & 0.70 & 12.1 & 21.3 \\
\hline $\begin{array}{l}\text { Lime } \\
\text { stone }\end{array}$ & 0.1 & 56.0 & 1.10 & 0.15 & 1.15 & 0.1 & 0 & 2.62 & 2.93 & 0.94 & 10.6 & $\longrightarrow$ \\
\hline Coke & 2.4 & 0.8 & 6.30 & 3.30 & 0.35 & 1.3 & 0 & 1.00 & 1.95 & 0.94 & 48.7 & $-\ldots$ \\
\hline $\begin{array}{l}\text { Return } \\
\text { fine }\end{array}$ & 53.3 & 11.0 & 7.20 & 1.95 & 2.45 & 8.3 & 0 & 3.93 & 4.53 & 0.53 & 13.2 & $\ldots$ \\
\hline
\end{tabular}

された。

\section{$2 \cdot 2$ 基礎物性測定方法}

Table 1 に示された原料特性に関し鉱石粒子の気孔 率は JIS M8717による真密度測定值と 5〜2 $\mathrm{mm}$ 整粒粒 子の水中置換体積測走により求めた見掛密度測定值とか ら計算された。また鉱石中結介水の加熱脱水に基づく高 温粒子気孔率は $450^{\circ} \mathrm{C}, 2 \mathrm{~h}$ 加熱後の鉱石粒子について 问様の手法で計測された。詳細は前報》に記載した。鉱 石粒子径は乾燥後標準篩で篩分けを行いメディアン径で 表示した．鍋試験において焼結反心忍の進行に伴う層高方 问の収縮はメジャーを用いて測定し試験鍋装置の諸元 (内径 $300 \mathrm{~mm} \phi$ 高さ $300 \mathrm{~mm}$ ) と装入重量から蓠密度を 計算した，焼結完厂後の焼結ケーキ及び破砕後の 15 $20 \mathrm{~mm}$ 整精焼結鉱成品の気孔率計測は JIS M8717 真密 度測定法と JIS M8716の水銀置換による見掛密度測定 法を基準法としたが, 気孔の大きさ, 分布等の評価や試 料小法の制約から, 他に水置換法, 樹脂埋込切断面の画 像処理法及びパラフィン被履を施した水置換法など種々 の方法とも比較検討を行つた.

\section{3. 実験結果及び考察}

\section{$3 \cdot 1$ 焼結過程の層構造変化}

焼結鉱気孔の形成過程は焼結パレットへ擬似粒化され た原料が充塡層を形成する状態が出発点となる。この原 料充填構造中には鉱石粒子内部の気孔, 造粒時核粒子に 付着した粉粒子間の気孔および擬似粒子相互間の空隙が 含まれ，後述するように多量の空間体積が存在する.

Fig. 2 には点火開始時点を基準に焼結時の層収縮（焼 しまり）の経過を示した。この収縮経過によると前報7) で示した溶融率からみて溶融性の良好な銘柄 Aとそうで

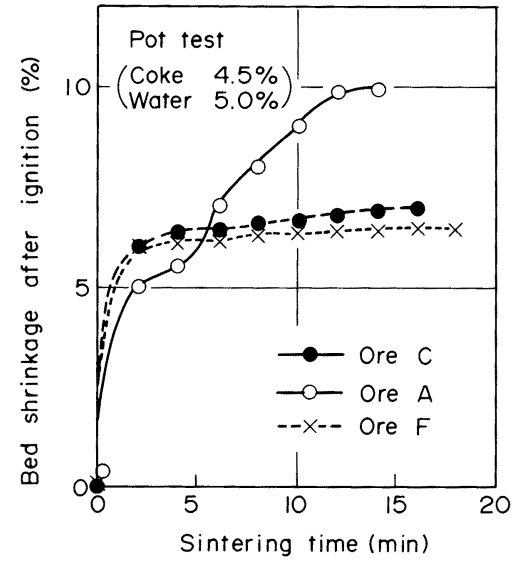

Fig. 2. Changes of bad shrinkage during sintering.

ない銘柄 $\mathrm{C}, \mathrm{F}$ とは明らかに収縮挙動に差が認められ る、いずれの鉱石銘柄も焼結過程のごく初期の数分閒以 内に急激に $6 \%$ 前後の収縮を生ずるが，溶融性の劣る 鉱石がその後焼結完了までゆるやかな増加をたどるのに 対して，溶融性良好な鉱石ではさらに第 2 段の大きな収 縮が生じ最終的に層収縮率は $10 \%$ にも達する，焼結反 応初期の急激な収縮は恐らく上層部の疎な充填構造と擬 似粒子の部分的崩壊に起因するものと考えられる。これ に対して第 2 の収縮变化は溶融の影響と考えられる.

Table 2 には実焼結機の配合原料を Fig. 1 に示す装 置を用いて層厚 $500 \mathrm{~mm}$, 焼成風速 $0.15 \mathrm{~m} / \mathrm{s}$ で焼結を 行つた時の焼結ケーキ層高別の物質収支結果を示した。 原料の層別装入量は各層の境界面にアルミナチップを マーカーとして少量散布しながら装入順に計量し，焼結 完了後ケーキはマーカーを目印に層別切断してそれぞれ 
Table 2. Structure change in sinter cake before and after sintering.

\begin{tabular}{|c|c|c|c|c|c|c|c|}
\hline \multirow[b]{3}{*}{ Layer } & \multicolumn{2}{|c|}{ Linear shrinkage $(\%)$} & \multicolumn{3}{|c|}{ Bulk density $\left(\mathrm{kg} / \mathrm{m}^{3}\right)$} & \multirow{3}{*}{$\begin{array}{c}\text { Mass } \\
\text { transfer } \\
(\mathrm{kg}) \\
\text { (Obs.-Calc.) }\end{array}$} & \multirow{3}{*}{$\begin{array}{c}\text { Calculated } \\
\text { voidage } \\
(\%)\end{array}$} \\
\hline & \multirow{2}{*}{ Vertical } & \multirow{2}{*}{ Radial } & \multirow{2}{*}{ Feed mix } & \multicolumn{2}{|c|}{ Sinter cake } & & \\
\hline & & & & Observed & Calculated & & \\
\hline Upper & 12.6 & 2.2 & 2007 & 1880 & 2118 & $\Theta 2.34$ & 46.3 \\
\hline Middle & 9.8 & 1.6 & 2039 & 2046 & 2061 & $\ominus 0.16$ & 41.6 \\
\hline Bottom & 9.1 & 1.0 & 2059 & 2309 & 2039 & $\oplus 2.84$ & 34.0 \\
\hline Total & 9.8 & 1.7 & 2041 & 1985 & 2066 & (†) 0.34 & 40.5 \\
\hline
\end{tabular}

Sintering conditions : $H=500 \mathrm{~mm} \quad v=0.15 \mathrm{~m} / \mathrm{s}$

の重量を計測した。焼絬後ケーキの計算嵩密度は焼成後 のケーキ寸法と配合原料中の気化物質の放出による重量 減少から尒測した。実測重量による訔密度は予測計算絈 果と大きく異なり，Table 2 に示すように焼結融体の流 動を介した層間の物質の移動が無視できない。この物質 の移動の影響は嵩密度で最大 $10 \%$ 以上の变化に相当 し，㘹結ヶーキの層高方向の空隙率に大きな差を作り出 している.

\section{$3 \cdot 2$ JIS 法で測定される気孔}

焼結鉱の見掛密度及び気孔率の計算は水銀中に焼結鉱 粒子を浸漬しその置換体積を計量することで求められ る。この場合の水銀の表面張力と固液界面の接触角及び 水銀中試料表面での压力を用いて焼結鉱試料の開気孔へ 水銀が侵入し得る限界気孔径を試算できる.

$$
P \cdot \pi r^{2}=-2 \pi r \cdot \sigma \cdot \cos \theta
$$

ここで, $P$ : 水銀中試料表面の压力 (深さ $5 \mathrm{~cm}$ ) $6800 \mathrm{dyn} / \mathrm{cm}^{2}, \sigma$ : 水銀の表媔張力 $478 \mathrm{dyn} / \mathrm{cm}, \theta$ : 接 触角 $108^{\circ}$ を代入すれば，気孔半径 $r=0.022(\mathrm{~cm})$ が求 められ，水銀の侵大し得る最小気孔径は $440 \mu \mathrm{m}$ と計算 される. Photo. 1 には透明容器の底面にあらかじめ切 断した焼結鉱の平面を接着して㧍き，これに水銀を蒲し た時の焼結鉱と水銀の接触状沉を容器底部からの写真で 示した．水銀と焼結鉱の接蚛界面では水銀の大きな表面 張力のために曲面となつた部分が白色の環となつて焼結 鉱の外周を覆つている。この白線の幅を桩大計測した結 果 $300 \sim 500 \mu \mathrm{m}$ 程度の值が得られ，上記の試算結果を 実験的に裏付けることができた。従つて JIS 法で計測 される焼結鉱の気孔率は，すべての閉気孔部分と約 500 $\mu \mathrm{m}$ 径以下の開気孔部分の合計の体積率を焅味する。

\section{$3 \cdot 3$ 焼結鉱粒径と気孔}

Table 3 には鉱石B単味配合鍋試験で製造された焼結 鉱の粒度区分別の全気孔率と JIS 気孔率測定結果を示 す。全気孔率，すなわち，焼結鉱粒子外部表面の曲率の 大きな凹部も気孔の一部として計測するために，粒子の 仮想外接曲面に沿つてできるだけ凹凸が少ないように， 軟化させたパラフィンを粒子表面に埋这みコーティング

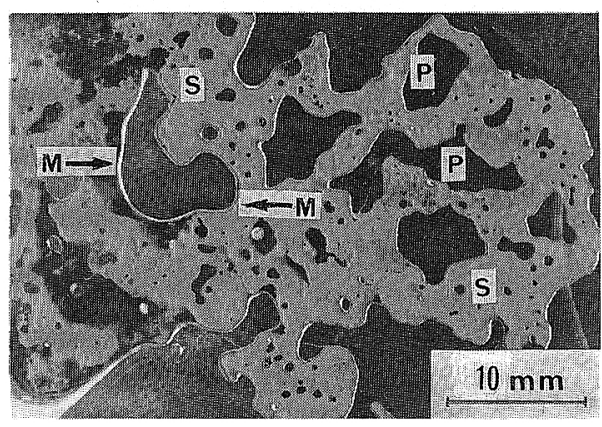

M : Mercury S: Sinter P : Pore

Photo. 1. Circumstances of interface between mercury and sinter.

Table 3. Total porosity and JIS porosity of different sized sinter*.

\begin{tabular}{|c|c|c|}
\hline Sinter size $(\mathrm{mm})$ & Total porosity (\%) & JIS porosity (\%) \\
\hline $20 \sim 18$ & 53.0 & 27.0 \\
\hline $16 \sim 15$ & 51.7 & 26.3 \\
\hline $13 \sim 10$ & 54.5 & 24.7 \\
\hline $5-4$ & 51.4 & 25.6 \\
\hline Mean value & 52.7 & 25.9 \\
\hline
\end{tabular}

処理を施した試料を水中に浸漬させその浮力からパラ フィン重量と体積を補正して，焼結鉱の全気孔率を測定 した。この絬果によれば全気孔率はいずれも50\% 強と

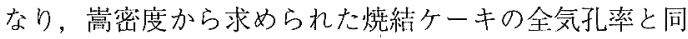
程度の值となつた。このことは焼結鉱粒子の外部表面に は本来破砕前焼結ケーキの空腺が大部分保存されている ことを物語つている。これに対して通常のJIS 気孔率 测定結果は全気孔率の $1 / 2$ 程度の值を示し JIS 気孔率は 焼結鉱の気孔の全量をとらえているわけではないが，冷 䦎强度や還元率と强い関係があることは周知の事実であ り，それと関連する欠㫟の一部を評価する指標と位置づ けられる。

Fig. 3 には焼結鉱粒子径とその中に含有される個数 基準の平均気孔径との関係を示す。測定は粒径の異なる 
Before treatment

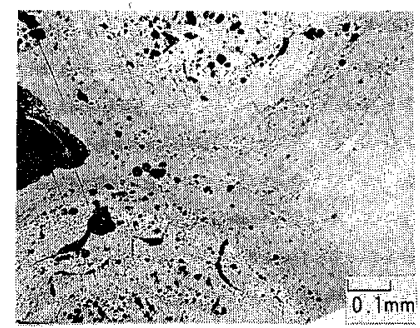

\section{After treatment}

$1 \mathrm{~min}$

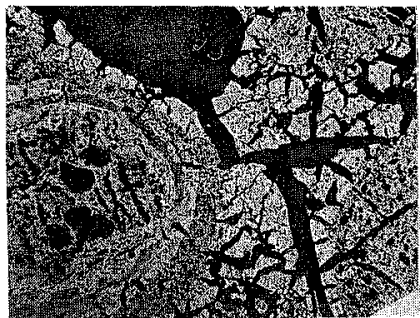

$2 \mathrm{~min}$.

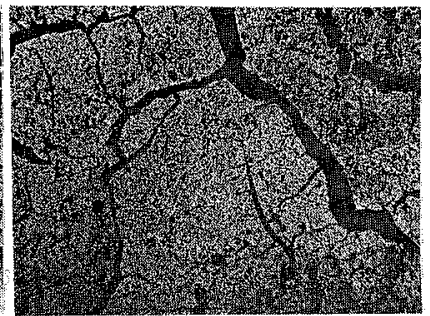

Photo. 2. Structure change of ore G before and after heat treatment.

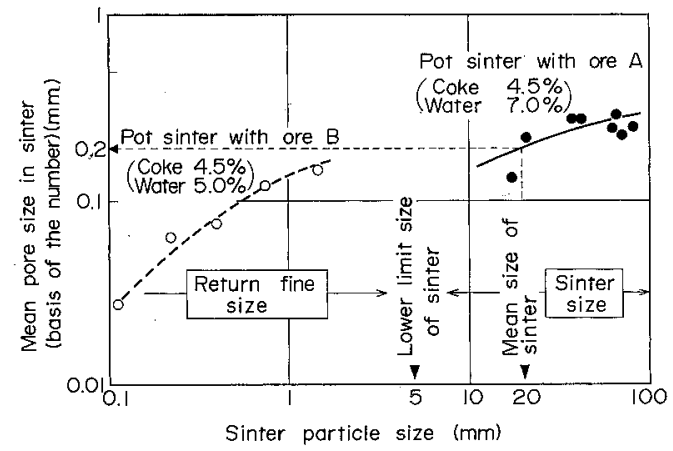

Fig. 3. Relationship between sinter particle size and the mean pore size in sinter.

整粒焼結鉱 2 種類について樹脂埋迟後切断面を研磨し写 真計測にて気孔のフェーレ径と個数を集計した。鉱石 B 単味配合焼絬鉱では 0.1-1 mm 粒子径の小粒径範围, 鉱石 $\mathrm{A}$ 焼結鉱の場合は 15 100 $\mathrm{mm}$ 径の大径粒子を試料 とした，通掌製造される焼結鉱成品の粒径範囲は 5 50 $\mathrm{mm}$ (平均径 $20 \mathrm{~mm}$ 前後) であるが，試料の種類と粒径 分布の应い割には平均気孔径の变化注少なく成品平均粒 子径での気孔平均径は約 $0.2 \mathrm{~mm}$ 程度であつた。従つて 焼結鉱成品中の気孔は焼結反応過程で層内の通気経路と なつていた大空隙ではなく鉱石粒内気孔やガスの発生に 関与した小気孔が主体と考えられる。

このようにJIS 法による気孔率は粒径に余り影響さ れないが，気孔径は粒子径が小さくなると減少する。粒 子径の減少による気孔径の低下は破砕度の上昇に伴う久 陥部の減少に関連するものと考えられる。

\section{$3 \cdot 4$ 鉱石銘唡特性の焼結鉱気孔率に及ぼす影響}

Fig. 4 には鉱石単味配合鍋試験によつて製造された 15 20 mm 径の銘柄別燒結鉱成品気孔率を示した。 の結果によれば褐鉄鉱系鉱石 $\mathrm{G} か ゙$ 最も高い気孔率を与无
逝に磁鉄鉱系鉱石 $\mathrm{E}, \mathrm{F}$ 户緻密質の赤鉄鉱系鉱石 $\mathrm{C}$ が低 く，他の鉱石はこれらの中間に位置する、襡鉄鉱系鉱石 の主姴酸化鉄仕X線回折結果からゲーサイト (Goethite, $\alpha-\mathrm{FeOOH}$ )であり ${ }^{8)}$ ，筧結度応の昇温過程でゲーサイ 卜の結晶格子から結合水の脱水が起こるために製造され る焼結鉱の気孔率が極めて高くなるものと考えられる.

Photo. 2 には鉱石 Gの等処理前後の組織の変化を示 した。熱处理条件は加熱炉中で焼絬ヒートパターンに準 じた急速昇温で $1200^{\circ} \mathrm{C}$ まで加熱しこの温度で数分間 保持した後徐冷した。この結果によれば加熱前の状態で

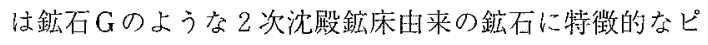
ソライト（Pisolite）棈造が散見され元来内部気孔の多 い組織となつている，熱処理後の組織では細いき裂が縦 横に発生するとともに結合水に相当していたと考えられ る部分の気孔が增加している。このような加熱後の弛緩 した鉱石構造は焼結の溶融過程で融液との接触界面積を 增して鉱石の見掛けの溶融速度を高めるとともに, 一少 では原料の気孔体積を增加させて製造される烧䋽鉱の気 孔梁を高列 ${ }^{9}$.

Fig. 5 左図では通常の鉱石 Gと熱処理を施した同鉱 石についてそれぞれ別々に単味配合鍋試験を同一の焼成 条件下で実施し，製造された焼結鉱の気孔率を対比して 示した。これら焼結鉱の気孔率はほほほ同等の值を示し， このことから燒結鉱の気孔の形成にとつて加等脱水する 水分々のものが作用するのではなく，脱水後の鉱石の気 孔率が支配的要因となることを意味している。また，同 右図に示されるように加熱脱水後の状態で計測された鉱 石の気孔率と製造される焼結鉱の気孔率とはかなりの強 い詨応性が認められるが、これだけで焼結鉱気孔率と鉱 石銘唡種との関係を説明することは因難である。その他 の要因として同図下表に示されるように，鉱石中の脈石 成分, 特に $\mathrm{Al}_{2} \mathrm{O}_{3}$ 量と気孔率とは良く対伈しており, 


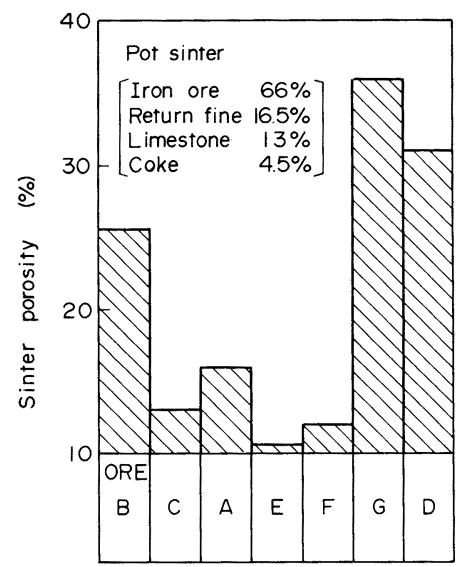

Fig. 4. Influence of iron ore brands on produced sinter porosity.

Table 4. Effects o fine sized ore mix on voidage and porosity in sinter product.

\begin{tabular}{c|l|l|l}
\hline \multicolumn{2}{c|}{ Items } & Base & \multicolumn{1}{c}{ Fine mix } \\
\hline \multirow{4}{*}{$\begin{array}{c}\text { Void \& } \\
\text { porosity }\end{array}$} & $\begin{array}{l}\text { Voidage in mix bed } \\
\text { Voidage in sinter cake }\end{array}$ & $57.70 \%$ & $58.85 \%$ \\
& $\begin{array}{l}\text { Porosity in sinter product } \\
\text { (JIS) } \\
\text { Porosity in sinter product } \\
\text { (Soaking in water) }\end{array}$ & 61.27 & 61.19 \\
& 14.5 & 20.7 \\
\end{tabular}

焼絬過程の高温で生成する融体の性質（粘度や鉱石との 好性）が焼結鉱の気孔形成に関与する叮能性を示唆す るものと考えられる。

次に原料鉱石䊀度の焼結鉱成品気孔率への影響につい て検得した. Table 4 には鉱不 $(B+C) 2$ 種類配合鍋

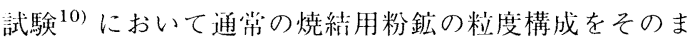
ま用いて配合したものと间一配令構成ながら主原料 2 種 鉱不の $5 \mathrm{~mm}$ 以上の粗粒部分を粉砕して金量 $5 \mathrm{~mm}$ 篩下 となるよう細䊀化した配介原料とを闹一焼成条件で焼結 した場命についてその気孔率を対比して示した。この結 果によれば焼結ケーキ全体に占める空隙率は通常粒度原 料と細粒原料とで大きな相違はない。これに対して，よ り小さな径の気孔を内包する焼結鉱成品の気孔率は明ら かに細粒原料使用の焼絬鉱のナが大きい。この差はさら に小さな径の気孔部分と密閉気孔を測定できる水中浸清

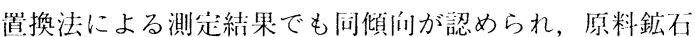
の細粒化は焼結鉱気孔率の上昇に有効である。

Fig. 6 にはこの両焼結鉱の切断面について顕微鏡に より気孔径区分ごとの面積率分布をポイントカウント法 で測乲した結果を示す。通常粒度原料による焼結鉱の気 孔径は $200 \mu \mathrm{m}$ から数 $\mathrm{mm}$ の範网に広く分布しているの に対し，細粒原料焼結鉱では $600 〜 800 \mu \mathrm{m} に$ にピークを

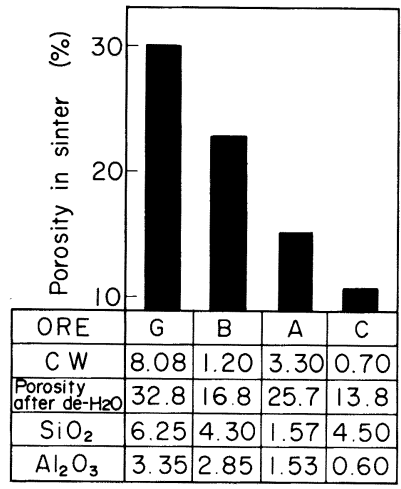

Fig. 5. Effect of iron ore characteristics on the porosity of sinter.

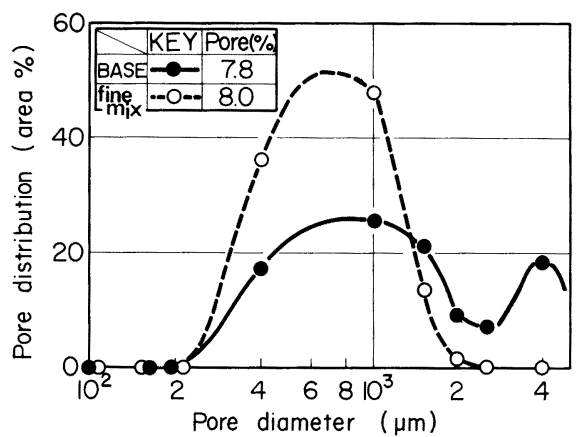

Fig. 6. Pore distributions in sinter (20-15 mm).

有する狭い分布に変化し， $2 \mathrm{~mm}$ 以上の粗大な気孔は少 ない.このように原料鉱石の細粒化は焼結鉱の粗大気孔 を減少させる一うで，人きさのそろつた小径気孔を増加 させる。

\section{$3 \cdot 5$ 焼結操業条件の焼結鉱気孔率に及ぼす影響}

Fig. 7 には操業条件として単味鈆石配合鍋試験にお ける粉コークス配合率及び原料水分添加率の焼結鉱成品 気孔率への影響を示す。3種の鉱份銘朒のいずれについ ても粉コークス配命率の上昇により気孔率は低下してい る.このようなコークス配令率の影響に比較して水分の 影響は明確ではない。この程度の操業条件の変更幅では まだ鉱石銘柄特性の影響が強く現れている。粉コークス 配会率の上昇は焼結層内高温保持時閆を延言化し熱的に 原料鉱石の溶融同化を促進するため，增量した融液は原 料光继層の空隙気孔を総体的に減少させる力向に作用し 製造される焼結鉱の気孔率低下に寄与する。従つて焼結 操業条件から見れば焼絬鉱気孔率のコントロールには焼 


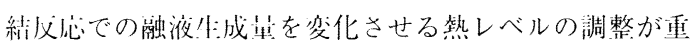
荌である。

次に焼結鉱父孔率に仪ばす $\mathrm{CaO}, \mathrm{SiO}_{2}$ 黾の影響につ いて検副した。尖焼絬機の配介に近似した原料を用いて 粉コークス配今率 $3.75 \%$, 皇料水分 $4.0 \%$ 一定の条件 下11)で，焼絬鉣全 $\mathrm{SiO}_{2}$ 量を珪们の添加により 3 水準,

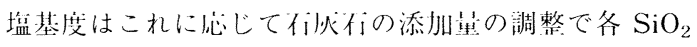
水準ごとにそれぞれ 6 水準変化させて烧結鉱父孔率への 影響を調查した。この絬果をFig. 8 にまとめて示す.

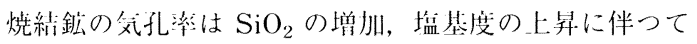

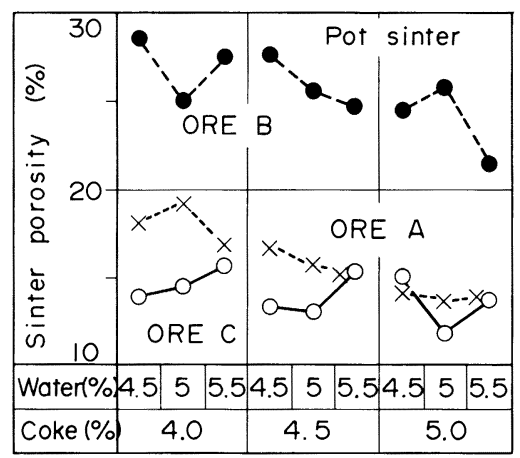

Water content of ore $\mathrm{A}$ : indicated value $+1.5 \%$

Fig. 7. Influence of sintering conditions on sinter porosity.

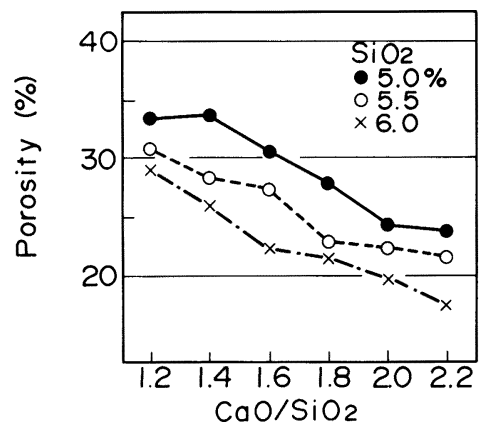

Fig. 8. Influence of basicity and $\mathrm{SiO}_{2}$ content in sinter on porosity of sinter.
平行迠線的に低下傾问を示した。これはスラグ構成成分 の增加による焼結文忍過程の融液生成量の増加と塩基度 の変化が融体の流動性を改善し充塡層空隙を減少させた 結果と考えられる.

以上のごとく主に実験結果を中心として焼結鉱父孔率 への影響要团とその効果について検傠してきたが，原料 特性の角では鉄鉱不そのものの性状と粒子往, 操業条作 からは焼絬反店時に生成する融液量とその性質が文配的 要素となつているものと考えられる.

\section{4. 気孔形成モデル}

Fig. 9 には焼結鉱気孔形成過程の概念㲸を示した。 第 1 段階は擬似粒化された原料充塤層が排風機の吸引力 で冷䦩の曾高収縮を生ずる. 実焼結機の場今には排風機 による吸引と層表面への点火がほぼ闰時に行われるた め, 実際上熱間收縮と冷閣収縮はまとめて詊価される。 原料充墴層内の空間は大きく二つに分類され，‥つは擬 似粒于内部の気孔でこれには鉱不粒子が本来保存する気 孔と核粒子の外挂付着微粉層に介在する気孔が含まれ る. 他の一つは擬似粒子同志の間隙に介在する管隙であ り,一般に前者に比較してより大きなサイズを持つと考 えられる.この原料允垻層は第 2 段階として廨表面への 点火に引き続き焼結父忍が進行し，最終的に大塊ブロッ ク状の焼結ケーキが形成される. 昇温加熱過程では付着 水分や鉱石中結令水の脱水と粉コークス拉よび石汽不の 一部が気化して加熱以前に固体または液体として占们し ていた空間は新たに気孔となる。さらに高温下では鈗不 と媒溶材の溶融流動化が生じて粒子間空隌を埋め, 全体 として気孔空隙の再配㯰と層の緻密化が進行する. 最終 段階は焼結ケーキの破砕に伴つて見掛け上気孔䅉隙の消 滅が起こり, 比較的小さな気孔が焼結鉱成品に残存し, これはJIS 気孔率測定法に基づいて計測される。

\section{$4 \cdot 1$ 焼結ケーキ気孔率}

Fig. 9 の模式汹にて原料充壃層の初期装入愿高を $H$, 冷間収縮量 $h_{1}$, 熱間収縮量 $h_{2}$ とし, さらに擬似粒子内 気孔率 $\varepsilon_{1}$, 擬似粒子間空隙率 $\varepsilon_{2}$, 焼結過程での原料中 気化物質の体積㳯 $R_{v}$ 及攵充填層の平均断面積を $A$ と

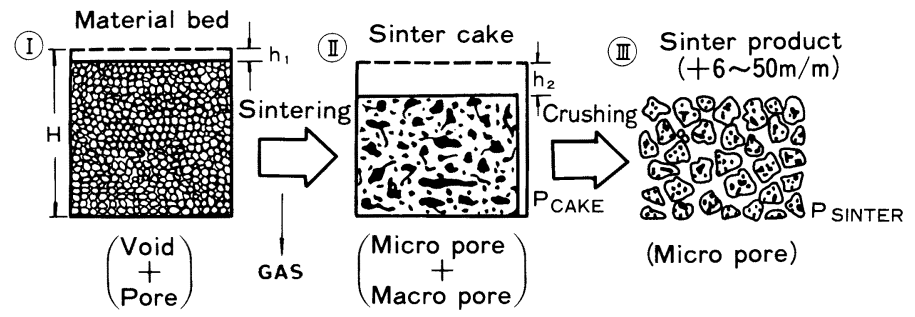

$-59-$
Fig. 9. General conception of sinter pore formation. 


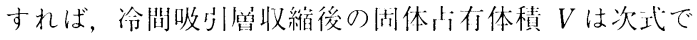
表される。

$$
V=\left(H-h_{1}\right) \cdot A \cdot\left(1-\varepsilon_{1}\right)\left(1-R_{v}\right) \cdots \cdots(1)
$$

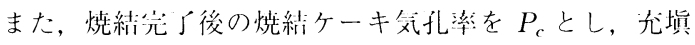

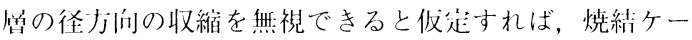
キ中の周体占存体稓 $V$ は焼結义文心の前後で变わらずに 保份され,

$$
V=\left(H-h_{1}-h_{2}\right) \cdot A \cdot\left(1-P_{c}\right)
$$

と表現される.

(1)，（2）式より焼絬ケーキ気孔率 $P_{c}$ は

$$
\begin{aligned}
& P_{c}=1-\left\{\left(H-h_{1}\right) /\left(H-h_{1}-h_{2}\right)\right\} \\
& \quad\left(1-\varepsilon_{1}\right)\left(1-\varepsilon_{2}\right)\left(1-R_{v}\right) \cdots \cdots \ldots \ldots . . .
\end{aligned}
$$

と求められる.

（3）式において原料初期層高の基準を装人時点でなく

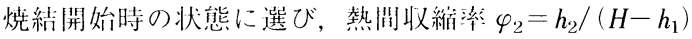
を分義すれば，（3）式は以下に変換される.

$$
P_{C}=1-\left\{1 /\left(1-\varphi_{2}\right)\right\}\left(1-\varepsilon_{1}\right)\left(1-\varepsilon_{2}\right)\left(1-R_{v}\right)
$$

ここで熱間仪綃率 $\varphi_{2}(-)$ は実測值であるが次式のよ うに融体荲とその性所とを要州としてモデル計算を川能 とした。

$$
\varphi_{2}=0.147 Q-0.0512 \varphi_{1}+0.0715
$$

ここで，融体量には朔報7)でホした溶融率 $Q(一)$ を 用い，融体の性質を代表する流動性指数 $\varphi_{1}(-)$ は（6) 式により化峃成分（\%）の 1 次関数として与えた。

$$
\begin{aligned}
\varphi_{1} & =0.0157(\mathrm{CaO})+0.016\left(\mathrm{SiO}_{2}\right)-0.181\left(\mathrm{Al}_{2} \mathrm{O}_{3}\right) \\
& -0.1(\mathrm{MgO})+0.01(\mathrm{FeO})+1.0 \cdots \cdots \cdots \cdots(6)
\end{aligned}
$$

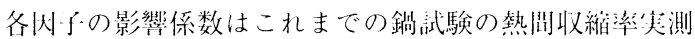
值と一致するようパラメーター・フィッティングで求め た。焼絬鉱成分 $(\mathrm{CaO}),\left(\mathrm{SiO}_{2}\right)$ 仪び $(\mathrm{FeO})$ は流動 性指数を高める力们に，( $\left.\mathrm{Al}_{2} \mathrm{O}_{3}\right)$ や $(\mathrm{MgO})$ 成分は逆 に低下させる力间の要因として作用する。各成分の中で $\left(\mathrm{Al}_{2} \mathrm{O}_{3}\right)$ の流動化抑制效果は係数的に影瑤が大きく前 们Fig. 5 の絬果とも整令する。(MgO) は高灯スラグ 糺成では流動性改善成分と位管づけられているが，焼綡 成分系では $\mathrm{MgO}$ 含们原料は一般に難溶融性と辣洒する 報年12) が多い。

次に（4）式に関して，擬似粒于内父孔摔 $\varepsilon_{1}($ ( ) ,

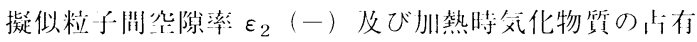
体箖率 $R_{v}($ （一）は，造精時添加水分による擬似粒子の 体積变化を無視すれば，それぞれ次式で近似できる。

$$
\begin{aligned}
& \varepsilon_{1}=\left(\rho_{2}{ }^{*}-\rho_{1}{ }^{*}\right) / \rho_{2}{ }^{*} \doteqdot 1-\left\{\rho_{1}\left(\rho_{2} \cdot w+1-w\right)\right\} / \\
& \left\{\bar{\rho}_{2}\left(\bar{\rho}_{1} \cdot w+1-w\right)\right\} \\
& \varepsilon_{2}=\left(\rho_{1}{ }^{*}-\rho_{3}{ }^{*}\right) / \rho_{1}{ }^{*} \doteqdot 1-\left\{\rho_{3}\left(\bar{\rho}_{1} \cdot w+1-w\right) / \bar{\rho}_{1}\right\}
\end{aligned}
$$

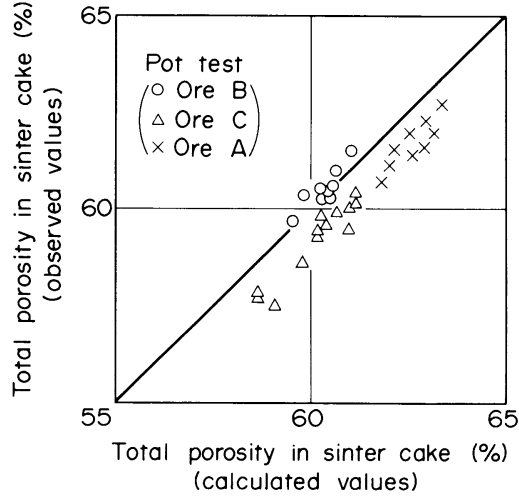

Fig. 10. Comparison between observed values of total porosity in sinter cake and calculated ones.

$$
\begin{aligned}
& R_{v}=0.85 \cdot C(1-w)+0.43 \cdot L(1-w) \\
& +W_{0}(1-w)+w
\end{aligned}
$$

ここで， $\rho_{1}{ }^{*}$ : 擬似粒子見掛密度 $\left(\mathrm{g} / \mathrm{cm}^{3}\right), \rho_{2}{ }^{*}$ : 擬似

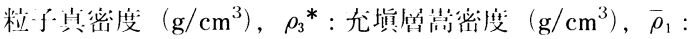
配全原料見掛密度 $\left(\mathrm{g} / \mathrm{cm}^{3}\right), \bar{\rho}_{2}$ : 配合原料思密度 $\left(\mathrm{g} / \mathrm{cm}^{3}\right)$,

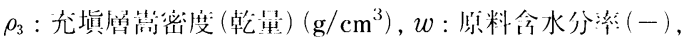

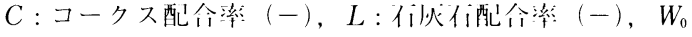

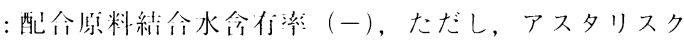
付きの記罗は湿星べース，C，L， $W_{0}$ は体䅡摔に換算

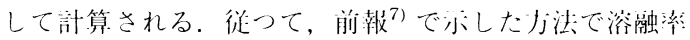

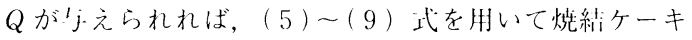

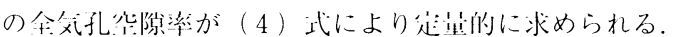

Fig. 10 には、記のモデルを用いて胡算したア測值と 尖測倠との対忍を亦した。この絬果によると㞹考はほぼ

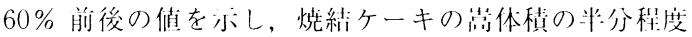

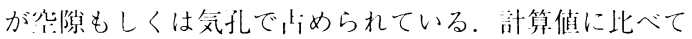
尖測值のうが約 $1 \%$ 低目に得られているが, 絶対储の 人きさからみて十分な舜測精度と誌われる。またここで

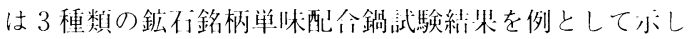
たが，鉱不銘柄別には鉱住 A が槀目，鉱们では低目の

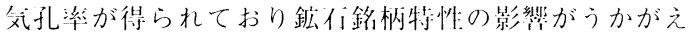
万.

\section{$4 \cdot 2$ 焼結鉱成品気孔率}

焼結ケーキの破砕整粒過程を経て製透される焼結鉙成 品中に残你する気孔の特徽として，これまでの実験絬果 からJIS 法で奏測される父孔は刘父孔のすべてと約 $0.5 \mathrm{~mm}$ 往以下の開気孔である。ここで焼結ヶーキの破 砕を経て焼結鉱成品に残留しJIS 法で計測される気孔 をミクロ父孔と足義し，その主な発牛源は原料鉱不擬似 档子内の初期ミクロ父北と仪起する。これに刘して，破 


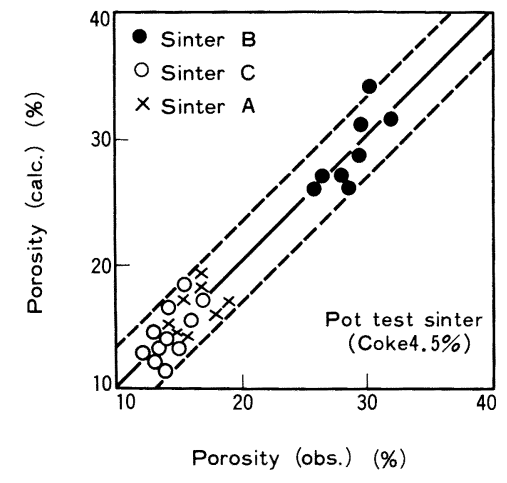

Fig. 11. Comparison between observed porosity in sinter and calculated one.

确時に見猢けた消隇する父孔をマクロ父孔と足:義しこ れは擬似档子望の初期マクロ気孔に主として山米するも の伐定する。

原料旮坦状態での初期ミクロ気孔率 $\varepsilon_{0}$ と初期マクロ 艾孔率 $E_{0}$ に夙して次式が成市する。

$$
\begin{aligned}
& \varepsilon_{0}=\varepsilon_{1}+R_{v} \\
& E_{0}=\varepsilon_{2} \cdots \cdots
\end{aligned}
$$

次に原料充垻層の鉱们の溶融に伴つて初期ミクロ気孔は 一部苓体してマクロ父孔に移行し，でき上がる焼結ケー キ中のミクロ笑孔率 $\varepsilon$ とマクロ㸚孔率 $E$ のバランスは, 溶融譬: $Q$ と融液流動性指数 $\varphi_{1}$ に依你して次式で表す.

$$
\begin{aligned}
& \varepsilon=\varepsilon_{0}-\varphi_{1} \cdot Q \cdot \varepsilon_{0}=\varepsilon_{0}\left(1-\varphi_{1} \cdot Q\right) \\
& E=E_{0}+\varphi_{1} \cdot Q \cdot \varepsilon_{0} \ldots \ldots \ldots \ldots \ldots \ldots \ldots \ldots \ldots \ldots \ldots
\end{aligned}
$$

これより，娔綃ケーキの破砕整粒によつて得られる焼絬 鉱成品父孔率 $P_{s}$ は，焼絬ケーキのマクロ気孔を除く全 体稓中のミク口気孔の㓶令で求められる。

$$
P_{s}=\varepsilon /(1-E) \text {. }
$$

Fig. 11 には鉱们 A，B 及びCそれぞれの単味配命鍋 試験によつて得られた焼綃鉱成思 3 種の気孔率实測値と 本モデルによる部算做との刘伈関係を示した。この結果 はほぼ
性状の晎なる鉱们配全が一律の関倸で整理され，他の鉣 不や多種銘柄の組全せ配命の場令にも適用川能と考えら れる。ここで焼絬操業条件が闰一の場令，鉱不B配令焼 結鉱は高い気孔率が得られる‥万で, 緻密質でミク口父 孔形成要因の少ない鉱不 Cや溶融性が艮好でミク口父孔 が減少する鉱石 $\mathrm{A}$ 配命焼結鉱の気孔率は低下し，令理似 な㖣明が叮能である。

\section{5. 結言}

焼結鉱品睤に大きな影響を及ぼす要因として，烧結鉱 気孔率は鉱物相構成とともに重要な役割をもつている。 焼絬鉱の気孔形成過程に関して基礎的な害験を行い，笑 験結果の解析に基づいて焼結鉱気孔率を従量的に推足以 能なモデルを開発した。モデルによる子測計算結果と各 種焼結鉱についての気孔率策測値とは鼓い一致をホし た。

今後は焼結鉱品質の这量推起モデルの開発を進める。

\section{文献}

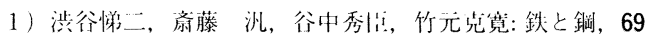
(1983), S 121

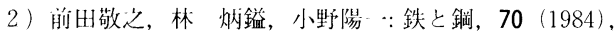
$\mathrm{S} 82$

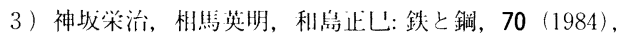
$\mathrm{S} 816$

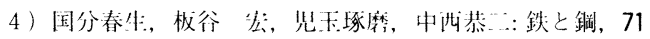
(1985), S 46

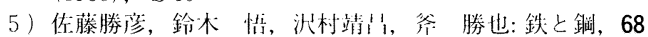
(1982), p. 2215

6) H本鉄鋼協会其间研究会製銑部公: 鉄と鍓，49（1963）, p. 1228

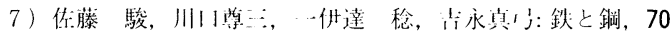
(1984), p. 657

$8) H$. Nola, $H$. Yanaka, $R$. Yamamoto, $H$. Kawata and Y. YAMAOKA: Trans. ISIJ, 25 (1985), p. 1103

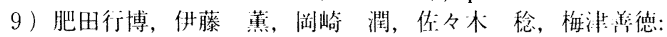
鉄と銅，68（1982）, p. 2166

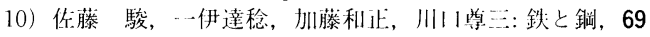
(1983), S 744

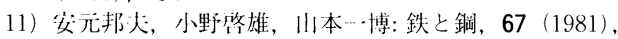
$\mathrm{S} 46$

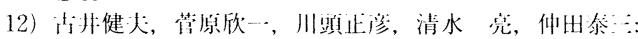
製鉄研究, 272 (1971), p. 9689 